\title{
COMPARISON OF THE CLINICAL EFFECTIVENESS OF LIDOCAINE HYDROCARBONATE AND LIDOCAINE HYDROCHLORIDE WITH AND WITHOUT EPINEPHRINE IN EPIDURAL ANAESTHESIA
}

\author{
R. Martin, Y. Lamarche and L. TÉTreault
}

\begin{abstract}
Epidural analgesia was administered to one hundred patients undergoing various types of surgical procedures. They were divided at random into four equal groups who received lidocaine hydrocarbonate or lidocaine hydrochloride, both with or without epinephrine. A double blind method was used. The study was designed first to test the validity of claims that lidocaine hydrocarbonate produces a shorter period of onset for effective analgesia, a more profound sensory and motor block, and a higher spread of analgesia than the hydrochloride salt and secondly, to identify the respective roles of carbon dioxide and epinephrine in obtaining this alleged superior effectiveness.

The results of the study showed that carbon dioxide improved the quality of sensory block, but we could not find any significant difference between lidocaine hydrocarbonate and lidocaine hydrochloride salt, with and without epinephrine, with regard to rapidity of onset, upward spread of analgesia and quality of motor block. As was already known, duration of analgesia was prolonged by the addition of epinephrine but not by the addition of carbon dioxide.

The study also showed that the compliance of the epidural space was decreased in the lidocaine hydrocarbonate groups compared to those with lidocaine hydrochloride. There is a positive correlation between the duration of sensory block or the upper level of analgesia and compliance in the hundred patients studied.

It is concluded that the hydrocarbonate base, because of its more profound sensory block in the $L_{5}-S_{1}$ segment, can be useful for operations on the lower extremities, especially in the $L_{5}-S_{1}$ segmental distribution. However, knowing that the hydrocarbonate base is more expensive, one must use his own judgment in appraising the cost-benefit of its use.
\end{abstract}

Key Words: Anaesthetic Techniques, Epidural; Anaesthetics, Local, lidocaine hydrocarbonate, lidocaine hydrochloride.

LIDOCAINE HYDROCARBONATE (Xylocaine $\mathrm{CO}_{2}{ }^{\mathbb{E}}$ ), in a concentration equivalent to that of lidocaine hydrochloride (both contain $1.73 \mathrm{mg}$ of lidocaine base per $\mathrm{ml}$ ) is claimed to be superior in clinical effectiveness to the hydrochloride salt because of its rapid onset of action and more profound motor and sensory blockage. ${ }^{1-4}$

The present double blind study was undertaken to test this hypothesis and at the same time to assess the relative importance of the effects of epinephrine and carbon dioxide on lidocaine epidural anaesthesia.

\section{METHOD}

One hundred patients (age $=49.4 \pm 19.6$ years, height $=167 \pm 9 \mathrm{~cm}$ ) undergoing various types of

R. Martin, M.D., F.R.C.P.(C), Assistant Professor, Department of Anaesthesia; Yves Lamarche, M.D., F.R.C.P.(C), Professor and Chairman, Department of Anaesthesia; L. Tétreault, M.D., M.Sc., F.C.C.P., Professor, Department of Medicine; Centre Hospitalier Universitaire de Sherbrooke, Sherbrooke, Québec, J1H 5N4. surgical procedures under peridural anaesthesia were included in the study. They were distributed in four groups of 25 patients according to a random numbers table. The four groups were comparable as to age, height and vascular status. Group I received $15 \mathrm{ml}$ lidocaine hydrochloride two per cent; group II, $15 \mathrm{ml}$ lidocaine hydrochloride two per cent with epinephrine 1:200,000 freshly added; group III, $15 \mathrm{ml}$ lidocaine hydrocarbonate and group IV, $15 \mathrm{ml}$ lidocaine hydrocarbonate with epinephrine 1:200,000 freshly added.

\section{Technique}

In all cases the epidural injection was done in the lateral position at the $\mathrm{L}_{3}-\mathrm{L}_{4}$ interspace and by the same anaesthetist. A 16 gauge Tuohy needle was inserted with the bevel directed cephalad and the epidural space was identified by the loss of resistance test with air. The speed of injection through the needle was kept constant at $0.6 \mathrm{ml} / \mathrm{sec}(15 \mathrm{ml}$ injected in 20 seconds). The sterile handling of the solutions was done out of

Canad. Anaesth. Soc. J., vol. 28, no. 3, May 1981 
sight and hearing of the anaesthetist by a technician and neither anaesthetist nor patient knew which of the solutions was being injected, or if epinephrine had been added or not. Six factors were evaluated: compliance of the epidural space, rapidity, quality, upper level and duration of sensory block, intensity of motor block.

\section{Compliance of the epidural space}

The epidural compliance was measured by visual evaluation of the volume of solution rejected through the needle after injection and graded 3 for no return of fluid, 2 for minimal and 1 for marked return. This test is crude but applicable to a clinical situation; it also has the ad vantage of being short enough to allow us to turn the patient on his back and to start measurements as quickly as possible. An epidural catheter was left in place for prolongation of anaesthesia when judged necessary.

\section{Evaluation of sensor and motor block}

All measurements were made on the side of the body dependent at the time of epidural administration. Analgesia levels were measured by the Wartenberg pinwheel at fixed intervals of $2,5,7$ and 10 minutes and then every five minutes afterwards until analgesia had regressed two segments. The duration of sensory bock was measured as the time required for two segments regression minus the time required to reach the upper level of analgesia (most cephalad dermatome made analgesic).

Quality of sensory block was measured twenty minutes after epidural injection by moving the Wartenberg pinwheel in the $L_{5}-S_{1}$ segmental dermatomes and a score of two was assigned to a complete sensory block, one for a partial block. The score 0 was to be reserved for absence of analgesia. Motor block was evaluated 30 minutes after epidural injection according to the Bromage Scale.'

\section{Statistical methods}

The four groups of patients were uniformly distributed in time. The results of quantitative data were subjected to analysis of variance for $2 \times 2$ balanced factorial plan. Ordinal data were submitted to the Mann Whitney U test. Spearman non-parametric correlation coefficient was used to study the statistical association between compliance and other variables.

\section{RESULTS}

\section{Interaction between carbon dioxide and epinephrine}

No interaction was found between carbon dioxide and epinephrine. Carbon dioxide does not modify the action of epinephrine and vice versa, epinehrine does not modify the action of carbon dioxide (Table I). This absence of interac-

\section{TABLE I}

Interaction of Carbon Dioxide and Epinephrine on Time Required to Reach the Upper level of ANalgesia, on DuRation of SENSORy Block, and on UpPER Level of ANalgesia ANalysis of Variance FOR FACTORIAL PLAN

$(n=2 \times 2 \times 25)$

\begin{tabular}{|c|c|c|c|c|}
\hline \multicolumn{2}{|l|}{ Variables } & $\begin{array}{c}\text { Time Required to } \\
\text { Reach Upper Level } \\
\text { of Analgesia } \\
\text { (Min) }\end{array}$ & $\begin{array}{c}\text { Duration of } \\
\text { Sensory Block } \\
\text { (Min) }\end{array}$ & $\begin{array}{l}\text { Upper Level } \\
\text { of Analgesia" }\end{array}$ \\
\hline \multicolumn{5}{|l|}{ Means } \\
\hline \multicolumn{2}{|l|}{$\begin{array}{l}\text { Lidocaine } \\
\text { Lidocaine }\end{array}$} & 16.00 & 34.24 & 8.36 \\
\hline \multicolumn{2}{|l|}{ + Epinephrine } & 15.48 & 62.60 & 8.92 \\
\hline \multicolumn{2}{|l|}{ Lidocaine $\mathrm{CO}_{2}$} & 13.24 & 32.56 & 8.32 \\
\hline \multicolumn{2}{|l|}{+ Epinephrine } & 14.08 & 65.28 & 8.68 \\
\hline \multicolumn{2}{|c|}{ Standard Error of the Means } & 1.419 & 6.000 & 0.501 \\
\hline \multirow{2}{*}{$\begin{array}{l}\text { Interaction } \mathrm{CO}_{2} \\
+ \text { Epinephrine } \\
\text { Analysis of Variance } \\
\qquad(\alpha=0.25)\end{array}$} & $\mathrm{F}$ & 0.23 & 0.13 & 0.040 \\
\hline & p & NS & NS & NS \\
\hline
\end{tabular}

*Figures shown correspond to number of Dermatomes blocked over $\mathrm{L}_{3}\left(0=\mathrm{L}_{3}, 1=\mathrm{L}_{2}, 2=\mathrm{L}_{1}, 8=\mathrm{T}_{7}, 9=\mathrm{T}_{6}\right.$, etc.). 
TABLE II

EfFects of Carbon Dioxide and Epinephrine on Time Required to Reach Upper Level of analgesia Analysis of Variance for Factorial Plan $(\mathrm{n}=2 \times 2 \times 25)$

\begin{tabular}{|c|c|c|c|c|c|c|}
\hline Factor Studied & Groups Compared & $\begin{array}{l}\text { Patients } \\
\text { number }\end{array}$ & $\begin{array}{l}\text { Means } \\
\text { (Min) }\end{array}$ & S.E.M.* & $\mathrm{F}$ & p \\
\hline \multirow{2}{*}{$\begin{array}{l}\text { Carbon } \\
\text { Dioxide } \\
\left(\mathrm{CO}_{2}\right)\end{array}$} & $\begin{array}{l}\text { Lidocaine } \\
+ \\
\text { Lidocaine Epinephrine }\end{array}$ & $25+25$ & 15.74 & \multirow{2}{*}{1.003} & \multirow[b]{2}{*}{2.15} & \multirow[b]{2}{*}{ NS } \\
\hline & $\begin{array}{l}\text { Lidocaine } \mathrm{CO}_{2} \\
\quad+ \\
\text { Lidocaine } \mathrm{CO}_{2} \text { Epinephrine }\end{array}$ & $25+25$ & 13.66 & & & \\
\hline \multirow{2}{*}{ Epinephrine } & $\begin{array}{l}\text { Lidocaine } \\
+ \\
\text { Locaine } \mathrm{CO}_{2}\end{array}$ & $25+25$ & 14.62 & \multirow{2}{*}{1.003} & \multirow{2}{*}{0.01} & \multirow{2}{*}{ NS } \\
\hline & $\begin{array}{l}\text { Lidocaine Epinephrine } \\
+ \\
\text { Lidocaine } \mathrm{CO}_{2} \text { Epinephrine }\end{array}$ & $25+25$ & 14.78 & & & \\
\hline
\end{tabular}

* Estimated by the experimental error of the analysis of variance.

TABLE III

Comparability of the Groups with Regard to Compliance (Scale: 1 to 3) Non-Parametric Tests of MANN-WHITNEY

\begin{tabular}{|c|c|c|c|c|c|c|}
\hline Factor Studied & Groups Compared & $\begin{array}{l}\text { Patients } \\
\text { Number }\end{array}$ & $\begin{array}{c}\text { Mean } \\
\text { (Scale: } 1 \text { to 3) }\end{array}$ & $\mathbf{U}$ & $\mathrm{Z}$ & $p$ \\
\hline \multirow{4}{*}{ Interaction } & Lidocaine & & & \multirow{4}{*}{1155.5} & \multirow{4}{*}{-0.72} & \multirow{4}{*}{ NS } \\
\hline & Lidocaine $\mathrm{CO}_{2}$ Epinephrine & $25+25$ & 2.30 & & & \\
\hline & Lidocaine Eninenhrine & & & & & \\
\hline & Lidocaine $\mathrm{CO}_{2}$ & $25+25$ & 2.42 & & & \\
\hline \multirow{4}{*}{$\begin{array}{l}\text { Carbon } \\
\text { Dioxide } \\
\left(\mathrm{CO}_{2}\right)\end{array}$} & Lidocaine & & & \multirow{4}{*}{989.0} & \multirow{4}{*}{-2.00} & \multirow{4}{*}{$<0.05$} \\
\hline & Lidocaine Epinephrine & $25+25$ & 2.52 & & & \\
\hline & Lidocaine $\mathrm{CO}_{2}$ & & & & & \\
\hline & Lidocaine $\mathrm{CO}_{2}$ Epinephrine & $25+25$ & 2.20 & & & \\
\hline \multirow{4}{*}{ Epinephrine } & Lidocaine & & & \multirow{4}{*}{1218.5} & \multirow{4}{*}{-0.24} & \multirow{4}{*}{ NS } \\
\hline & Lidocaine $\mathrm{CO}_{2}$ & $25+25$ & 2.34 & & & \\
\hline & Lidocaine Epinephrine & & & & & \\
\hline & Lidocaine $\mathrm{CO}_{2}$ Epinephrine & $25+25$ & 2.38 & & & \\
\hline
\end{tabular}

tion is true for the upper level of analgesia, the time required to reach it and the duration of sensory block. When used together each factor maintains its own effect, without potentiation or antagonism by the other. The effects of epinephrine could then be assessed on the pooled sample of patients who received lidocaine hydrochloride and lidocaine hydrocarbonate; in the same manner, the effect of carbon dioxide could be compared in a pool of patients who had received lidocaine anaesthesia with and without epinephrine. 
TABLE IV

Correlation Betiveen Compliance and the Variables Studied

\begin{tabular}{|c|c|c|c|c|}
\hline \multicolumn{2}{|r|}{ Variables } & \multicolumn{3}{|c|}{ Non-Parametric Correlation Analysis } \\
\hline $\begin{array}{l}\text { Independent } \\
\mathrm{X}\end{array}$ & $\underset{Y}{\text { Dependent }}$ & $\begin{array}{c}\text { Spearman's Coefficient }=R_{S} \\
(N=100)\end{array}$ & $\mathrm{T}_{\mathrm{RS}}$ & $\mathrm{p}$ \\
\hline \multirow{5}{*}{ Compliance } & Time Required for Upper Analgesic Level & +0.17 & 1.71 & NS \\
\hline & Duration of Sensory Block & +0.21 & 2.13 & $<0.05$ \\
\hline & Quality of Sensory Block & +0.13 & 1.30 & NS \\
\hline & Intensity of Motor Block & +0.07 & 0.69 & NS \\
\hline & Upper Level of Analgesia & +0.34 & 3.54 & $<0.001$ \\
\hline
\end{tabular}

TABLE $V$

EFFects of Carbon Dioxide and EPINEPHRINe on UPPER LeYel of ANalgesia ANalysis of Variance for Factorial Plan

$(\mathrm{n}=2 \times 2 \times 25)$

\begin{tabular}{|c|c|c|c|c|c|c|}
\hline Factor Studied & Groups Compared & $\begin{array}{l}\text { Patients } \\
\text { number }\end{array}$ & Mean* & S.E.M. & $\mathrm{F}$ & $\mathrm{p}$ \\
\hline \multirow{2}{*}{$\begin{array}{c}\text { Carbon } \\
\text { Dioxide } \\
\left(\mathrm{CO}_{2}\right)\end{array}$} & $\begin{array}{l}\text { Lidocaine } \\
\stackrel{+}{+} \\
\text { Lidocaine Epinephrine }\end{array}$ & $25+25$ & 8.64 & \multirow{2}{*}{0.354} & \multirow{2}{*}{0.08} & \multirow{2}{*}{ NS } \\
\hline & $\begin{array}{l}\text { Lidocaine } \mathrm{CO}_{2} \\
\quad+ \\
\text { Lidocaine } \mathrm{CO}_{2} \text { Epinephrine }\end{array}$ & $25+25$ & 8.50 & & & \\
\hline \multirow{2}{*}{ Epinephrine } & $\begin{array}{l}\text { Lidocaine } \\
+ \\
\text { Locaine } \mathrm{CO}_{2}\end{array}$ & $25+25$ & 8.34 & \multirow{2}{*}{0.354} & \multirow{2}{*}{0.84} & \multirow{2}{*}{ NS } \\
\hline & $\begin{array}{l}\text { Lidocaine Epinephrine } \\
\quad+ \\
\text { Lidocaine } \mathrm{CO}_{2} \text { Epinephrine }\end{array}$ & $25+25$ & 8.80 & & & \\
\hline
\end{tabular}

*Most cephalad Dermatome made analgesic to pinprick $\left(0=\mathrm{L}_{3}, 1=\mathrm{L}_{2} \ldots . .9=\mathrm{T}_{6}\right.$, etc. $)$

Rapidity of onset of sensory block

Neither carbon dioxide or epinephrine significantly shortened the time required to reach the uppermost level of analgesia (Table II).

Compliance of the epidural space, upper level of analgesia and duration of sensory block

When carbon dioxide was present in the solution administered the compliance of the epidural space was found to be decreased ( $p<0.05$ ) (Table III). A correlation study was carried out between the independent variable compliance and the five other dependent variables studied in the one hundred patients. (Table IV). Compliance was found to be positively correlated with duration $(p<0.05)$ and analgesic level $(p<0.001)$.

By analysis of variances, we found no signifivant effect of carbon dioxide on the upward spread of analgesia and duration of sensory block
(Table V). This conclusion may have been influenced by the fact that compliance is lower in carbon dioxide groups and that compliance is positively correlated with duration and level of analgesia. To correct the effect of this bias we have submitted the same data to the analysis of covariance using the compliance index as a covariate. We reached the same conclusions and found no significant effect of carbon dioxide on duration and level of analgesia.

Epinephrine, as expected, lengthened the sensory block significantly (Figure 1).

\section{Quality of sensory block}

All patients had some degree of analgesia; score 0 (absence of analgesia) was never assigned. Analysis of results showed an improvement in the quality of sensory block when carbon dioxide was used $(\mathrm{p}<0.05)$ (Table VI). 


\section{Discussion}

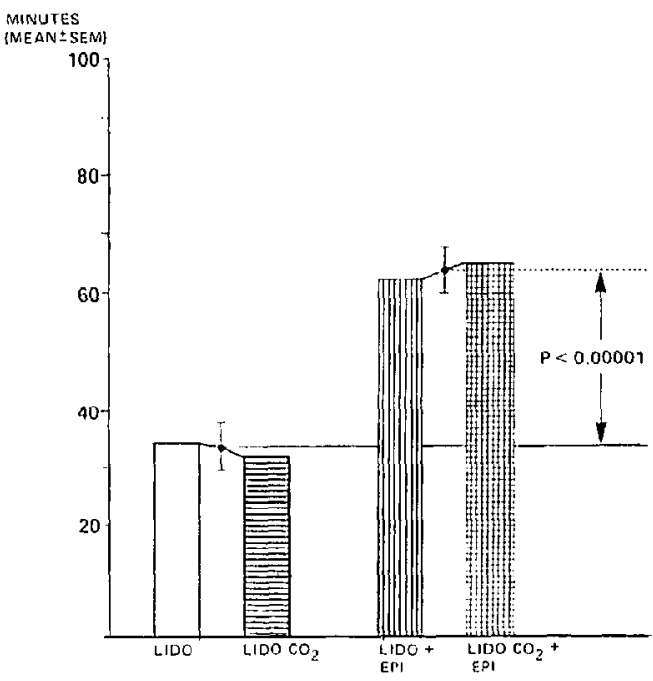

FIGURE 1 Effect of epinephrine on the duration of sensory analgesia after epidural anaesthesia with lidocaine hydrocarbonate or lidocaine hydrochloride.

\section{Intensity of motor block}

Neither carbon dioxide or epinephrine had any significant effect on the intensity of motor block at 30 minutes after epidural injection, and no interaction was found between the variables (Table VII).
Lidocaine hydrocarbonate has been used extensively in Canada for epidural anaesthesia because of its proposed superior clinical effectiveness when compared to the hydrochloride salt. To our knowledge, the double blind method for comparing the forms of lidocaine with and without epinephrine had not been utilized in previous studies, nor had the relative importance of carbon dioxide and epinephrine been specifically studied.

Using the pinprick method in the segmental dermatomes of $L_{5}$ and $S_{1}$, whose roots are the largest and consequently the most difficult to block effectively, we found that lidocaine hydrocarbonate produced a more profound sensory block than the hydrochloride salt. We think that this effect could be important when operations are to be done on the lower extremities, where a high percentage of failures is encountered with epidural analgesia, especially in the $L_{5}-S_{1}$ segmental distribution.

Even if our clinical impression before the study had been that lidocaine hydrocarbonate was more rapid in reaching its complete spread and its surgical effectiveness, we did not find a statistically significant difference between the two forms of lidocaine in that respect.

TABLE VI

Influence of Carbon Dioxide and Epinephrine on the Quality of Sensory Block (Scale: 0 to 2) Non-Parametric Tests of ManN-Whitney

\begin{tabular}{|c|c|c|c|c|c|c|}
\hline Factor Studied & Groups Compared & $\begin{array}{l}\text { Patients } \\
\text { Number }\end{array}$ & $\begin{array}{c}\text { Mean } \\
\text { (Scale: } 0 \text { to 2) }\end{array}$ & $\mathrm{U}$ & $\mathrm{Z}$ & p \\
\hline \multirow{5}{*}{ Interaction } & Lidocaine & & & \multirow{5}{*}{1234.5} & \multirow{5}{*}{-0.13} & \multirow{5}{*}{ NS } \\
\hline & Lidocaine $\mathrm{CO}$, Epinephrine & $25+25$ & 1.62 & & & \\
\hline & $I$ id & \multirow{3}{*}{$25+25$} & \multirow{3}{*}{1.62} & & & \\
\hline & Lidocaine & & & & & \\
\hline & Lidocaine $\mathrm{CO}_{2}$ & & & & & \\
\hline \multirow{5}{*}{$\begin{array}{l}\text { Carbon } \\
\text { Dioxide } \\
\left(\mathrm{CO}_{2}\right)\end{array}$} & Lidocaine & & & \multirow{5}{*}{968.5} & \multirow{5}{*}{-2.31} & \multirow{5}{*}{$<0.05$} \\
\hline & Jishomine Eninantrine & $25+25$ & 1.50 & & & \\
\hline & & & & & & \\
\hline & Lidocaine $\mathrm{CO}_{2}$ & & & & & \\
\hline & Lidocaine $\mathrm{CO}_{2}$ Epinephrine & $20+25$ & 1.14 & & & \\
\hline \multirow{4}{*}{ Epinephrine } & Lidocaine & & & \multirow{4}{*}{1018.0} & \multirow{4}{*}{-1.91} & \multirow{4}{*}{ NS } \\
\hline & Lidocaine $\mathrm{CO}_{2}$ & $25+25$ & 1.52 & & & \\
\hline & Lidocaine Epinephrine & & & & & \\
\hline & Lidocaine $\mathrm{CO}_{2}$ Epinephrine & $25+25$ & 1.72 & & & \\
\hline
\end{tabular}


TABLE VII

Influence of Carbon Dioxide and Epinephrine on Motor Block (SCale: 0 to 2) Non-Parametric Tests OF MANN-WHITNEY

\begin{tabular}{|c|c|c|c|c|c|c|}
\hline Factor Studied & Groups Compared & $\begin{array}{l}\text { Patients } \\
\text { Number }\end{array}$ & $\begin{array}{c}\text { Mean } \\
\text { (Scale: } 0 \text { to } 2 \text { ) }\end{array}$ & $\mathbf{U}$ & $\mathrm{Z}$ & p \\
\hline \multirow{2}{*}{ Interaction } & $\begin{array}{l}\text { Lidocaine } \\
\quad+ \\
\text { Lidocaine } \mathrm{CO}_{2} \text { Epinephrine }\end{array}$ & $25+25$ & 0.84 & \multirow{2}{*}{1193.5} & \multirow{2}{*}{-0.42} & \multirow{2}{*}{ NS } \\
\hline & $\begin{array}{l}\text { Lidocaine Epinephrine } \\
+ \\
\text { Lidocaine } \mathrm{CO}_{2}\end{array}$ & $25+25$ & 0.78 & & & \\
\hline \multirow{2}{*}{$\begin{array}{l}\text { Carbon } \\
\text { Dioxide } \\
\left(\mathrm{CO}_{2}\right)\end{array}$} & $\begin{array}{l}\text { Lidocaine } \\
\quad+ \\
\text { Lidocaine Epinephrine }\end{array}$ & $25+25$ & 0.70 & \multirow{2}{*}{1095.0} & \multirow{2}{*}{-1.16} & \multirow{2}{*}{ NS } \\
\hline & $\begin{array}{l}\text { Lidocaine } \mathrm{CO}_{2} \\
\quad+ \\
\text { Lidocaine } \mathrm{CO}_{2} \text { Epinephrine }\end{array}$ & $25+25$ & 0.92 & & & \\
\hline \multirow{2}{*}{ Epinephrine } & $\begin{array}{l}\text { Lidocaine } \\
+ \\
\text { Lidocaine } \mathrm{CO}_{2}\end{array}$ & $25+25$ & 0.68 & \multirow{2}{*}{997.5} & \multirow{2}{*}{-1.89} & \multirow{2}{*}{ NS } \\
\hline & $\begin{array}{l}\text { Lidocaine Epinephrine } \\
+ \\
\text { Lidocaine } \mathrm{CO}_{2} \text { Epinephrine }\end{array}$ & $25+25$ & 0.94 & & & \\
\hline
\end{tabular}

As expected, duration of analgesia was markedly prolonged by epinephrine but was not modified in the same way by carbon dioxide. Contrary to what has been reported earlier, ${ }^{1}$ the intensity of motor blockage was not significantly increased by either epinephrine or carbon dioxide.

When lidocaine hydrocarbonate was used, a marked modification of compliance of the epidural space was found. Even if our method for testing compliance was crude, the results of that aspect of our study have to be reported because of their strong significance. All groups of patients being comparable and, as the speed of injection was kept constant, the larger volume of lidocaine hydrocarbonate rejected after injection had to carry some impact on the evolution of analgesia. Indeed, decreased compliance has a negative effect on duration of sensory block and upper level of analgesia. However, the hypothesis of a larger return of lidocaine hydrocarbonate caused by a raised epidural pressure according to Henry's and Charles' laws cannot be eliminated. This aspect of our study deserves further investigation.

Because of this bias introduced by the effect of carbon dioxide on compliance, we submitted all the data to the analysis of covariance using the compliance index as a covariate. The adjustment for compliance did not modify any of our conclusions.

Consequently, our study did not show that for lidocaine "the mere change of salt from a hydrochloride to a carbonated base can convert a mediocre drug to a star performer, with vivid action and commanding intensity," 6 but that the hydrocarbonate base can be useful in specific circumstances. The reader knowing that the cost of lidocaine hydrocarbonate is three times the cost of the hydrochloride salt should use his ow'n judgment in appraising the cost-benefit of its use.

\section{ACKNOWLEDGMENT}

To the technicians, secretaries and to the medical staff of the Department of Anaesthesia for their assistance in the realization of this study. Lidocaine (Xylocaine $\left.{ }^{\otimes}\right)$ used in this study was supplied by Astra Pharmaceutical.

\section{REFERENCES}

1. Bromage, P.R. A Comparison of the Hydrochloride and Carbon Dioxide Salts of Lidocaine and Prilocaine in Epidural Analgesia. Acta Anaesth. Scand. Suppl. XVI: 55 (1965). 
2. Bromage, P.R., Burfoot, M.F., Crowell, D.G. \& Truant, A.P. Quality of Epidural Blockade Ill: Carbonated Local Anaesthetic Solutions. Br. J. Anaesth. 39: 197 (1967).

3. Bromage, P.R. \& Gertel, M. An Evaluation of Two New Local Anaesthetics for Major Conduction Blockage. Canad. Anaesth. Soc. J. 17: 557 (1970).
4. Catchlove, R.F.H. The Influence of $\mathrm{CO}_{2}$ and $\mathrm{pH}$ on Local Anesthetic Action. J. Pharmacol. Exp. Ther. $181: 298$ (1972).

5. Bromage, P.R. Epidural Analgesia, Ist Edition, Philadelphia, Saunders, p. 314 (1978).

\section{RÉSUMÉ}

Cent patients soumis à divers types de chirurgie sous anesthésie épidurale ont été étudiés. Les patients ont été répartis au hasard en quatre groupes de vingt-cinq malades chacun. Selon la technique de double insu, les patients ont reçu de la lidocaine hydrocarbonatée ou hydrochlorée, avec ou sans adrénaline. L'étude avait pour but premier de vérifier le bien fondé des avantages suivants attribués à la lidocaïne carbonatée sur la lidocaïne hydrochlorée: une plus grande rapidité d'action, une supériorité dans la qualité du blocage sensitif et moteur produit, des niveaux d'analgésie plus élevés. En second lieu, l'étude avait pour but d'évaluer les rôles respectifs du $\mathrm{CO}_{2}$ et de l'adrénaline sur les variables étudiées. La compliance de l'espace épidural et la durée d'analgésie ont également été étudiés.

$L$ 'étude a montré que le $\mathrm{CO}_{2}$ augmente la qualité du blocage sensitif, mais nous n'avons pas retrouvé de différence significative entre la lidocaine carbonatée et la lidocaïne hydrochlorée, a vec ou sans adrénaline, en ce qui a trait à la rapidité d'action, au niveau supérieur d'analgésie et à la qualité du blocage moteur produit. La durée d'analgésie a été prolongée par l'adrénaline, mais n'a pas été influencée parle $\mathrm{CO}_{2}$. La présente étude a également montré que la compliance de l'espace épidural était moins grande che $z$ les patients qui ont reçu la solution carbonatée comparée à ceux qui ont reçu la solution hydrochlorée, et qu'il y a une corrélation positive entre, d'une part la compliance et d'autre part la durée du blocage sensitif et le niveau d’analgésie.

Nous concluons que la lidocaine carbonatée, en raison de la qualité du blocage sensitif produit dans le territoire de $\mathrm{L}_{5}-\mathrm{S}_{1}$, peut ètre utile dans la chirurgie du membre inférieur, surtout si cette chirurgie a lieu au niveau de ces dermatomes. Cependant, vu son coùt plus élevé, chacun doit évaluer son coût-bénéfice avant de l'utiliser. 